\title{
LEITE DERRAMADO: Uma narrativa da decadência do Brasil
}

\author{
LEITE DERRAMADO: A narrative of the decline of Brazil
}

\author{
Alice Atsuko Matsuda ${ }^{1}$ \\ Angela Maria Rubel Fanini ${ }^{2}$ \\ Wilton Fred Cardoso de Oliveira ${ }^{3}$
}

\section{Resumo}

Este artigo apresenta a leitura da obra Leite Derramado (2009), de Chico Buarque de Holanda, a partir do pressuposto de que esse escritor insere-se na tradição literária nacionalista, constituindo-se como o mapeador do Brasil do século XIX e XX. Parte-se do princípio de que Buarque retoma a tradição, redefinindo-a, reconsiderando o passado nacional e levando em consideração o presente. Procuramos averiguar como ocorre a formalização literária de certa identidade nacional, a partir, sobretudo das ideias de Candido (2000), investigando como o romancista extrai dos dados externos a matéria ficcional e como a constrói em dados internos ao texto. Da mesma forma, se averigua como Buarque revisita os discursos nacionalistas literários anteriores a ele. Também nos pautamos nos intérpretes da tradição, a exemplo de Holanda(1995) e Freyre(1977), a fim de verificarmos como o autor de Leite Derramado recupera a tradição e avalia as contradições e continuidades históricas. Ao término da análise, constatou-se que há uma visão arquitetônica parcialmente desiludida em relação ao tempo presente e uma certa perspectiva saudosista e positiva frente ao passado nacional.

Palavras-chave: Tradição. História. Formação da identidade brasileira. Literatura Contemporânea. Chico Buarque de Holanda. Leite Derramado.

\begin{abstract}
This paper analyses the novel Leite Derramado (2009) written by Chico Buarque de Holanda, a Brazilian novelist, perceiving his writing inside a literary nationalist tradition which was reinforced in the nineteenth century by other Brazilian novelists at that time. We have researched how Buarque continues that tradition, redefining it, reconsidering the past and taking into account the contemporary reality. Using Candido (2000) ideas, we studied how the author deals with the intersection between reality, literary discourses and fiction. Considering this background, it was studied how extra verbal Brazilian setting migrates to the text, portraying a certain Brazilian identity. Holanda (1995) and Freyre (1977), Brazilian intellectuals, whose writings deals with the formation of the Brazilian society, also help the investigation, in order to understand how Buarque reinserts his novel into tradition and,

\footnotetext{
${ }^{1}$ Graduação em Letras Anglo-Portuguesas pela UEL, Mestrado em Letras - Literatura e Ensino - pela Unesp/Assis (2001), e Doutorado em Letras - Estudos Literários - pela UEL (2009). Professor adjunto da Universidade Tecnológica Federal do Paraná, campus Curitiba. E-mail: alicem@utfpr.edu.br

2 Graduação em Letras Português-Inglês pela UFPR (1987), Mestado em Letras pela UFPR (1991), Doutorado em Teoria da Literatura pela UFSC (2003). Concluiu estágio pós-doutoral na Universidade de Aveiro, Portugal, como membro da Linha de Pesquisa Representações de Portugal nas Literaturas Estrangeiras e do Estrangeiro na Literatura Portuguesa (2009). Professora da UTFPR e atua no Programa de Pós-Graduação e Tecnologia da UTFPR, na Linha de Pesquisa Tecnologia e Trabalho - TT. Bolsita em Produtividade em Pesquisa pela Fundação Araucária, Paraná. E-mail rubel@utufpr.edu.br

${ }^{3}$ Graduação em Letras pela PUC-PR (1983), graduação em Filosofia pela UFPR (1998), Mestrado em Literatura pela UFSC (2000) e Doutorado em Literatura pela UFSC (2005). Professor de ensino tecnológico da UTFPR. E-mail: wilfred@utfpr.edu.br
} 
simultaneously, portrays its discontinuity and contradictions. The results show that Buarque presents a certain dismayed vision to the present times and a positive perspective towards the Brazilian past.

Key words: Tradition. History. Brazilian identity. Contemporary literatura. Chico Buarque de Holanda. Leite Derramado.

Poucos são os netos de agricultores que se conservam à frente das propriedades que seus pais herdaram; o adágio "pai rico, filho nobre, neto pobre” expressa a longa experiência popular dos hábitos da escravidão, que dissipam todas as riquezas, não raro no estrangeiro. $^{4}$

O romancista José Martiniano de Alencar “imagina dar à sua obra um sentido de levantamento do Brasil, como deixa indicado no prefácio de Sonhos d'Ouro" 5 . O seu arcabouço literário se constitui num grande mapeamento do Brasil, no século XIX. Cultiva, por ser homem de um determinado tempo e de seu País, romances regionalistas, urbanos, históricos, repletos de alusões à política do império, romances denominados também de fazendeiros, a exemplo de O Tronco do Ipê e Til, e romances indianistas ou mítico-fundacionais: O Guarani, Iracema e Ubirajara. Suas narrativas retratam os aspectos culturais do Norte ao Sul do Brasil, inventando para a nação uma tradição. Ou parafraseando as palavras de Eric Hobsbawn, em A Invenção das Tradições $^{6}$, fazendo com que um conjunto de práticas que ainda não estavam visíveis para o povo brasileiro, mas que se constituíam como regras aceitas viessem à visibilidade, inculcando valores e normas de comportamento, criando assim uma continuidade em relação ao passado. Alencar contribuiu para configurar o Brasil, tornando possível ao povo contar histórias de si para si, confirmando o papel da literatura como uma forma de conhecimento. Num século em que as nações começam a se configurar, a literatura surge como um fenômeno histórico, capaz de exprimir o espírito nacional.

Se o Brasil era uma nação, deveria possuir espírito próprio como efetivamente manifestara pela proclamação da Independência; decorria daí, por força, que tal espírito

\footnotetext{
${ }^{4}$ De Joaquim Nabuco, O Abolicionismo, cit. In: FREYRE, Gilberto. Casa Grande e Senzala, cap. III. Rio de Janeiro: Aguilar, 1977, p. 282

${ }^{5}$ CANDIDO, Antonio. Formação da Literatura Brasileira, vol.2. 8a Ed. - Belo Horizonte - Rio de Janeiro: Itatiaia, 1997, p. 201.

${ }^{6}$ HOBSBAWN, Eric. A Invenção das Tradições. 3. Ed. Rio de Janeiro: Paz e Terra, 1997, p. 9.
} 
deveria manifestar-se na criação literária que sempre o exprimia, conforme as teorias do momento. ${ }^{7}$

Essa foi a consciência e grandeza de José de Alencar partilhada por outros escritores do século XIX. Por sorte, a empreitada de mapear a nação desse romancista não ficou no passado. No século XX e contemporâneo, a despeito de toda uma crítica literária quase que omissa, o facho Martiniano não foi lançado ao esquecimento. Da mesma forma que esse romancista, Chico Buarque trouxe não somente o externo dos tempos hodiernos, mas debruçou-se e debruça-se sobre a história do Brasil, resgatando as suas raízes, a alma brasileira, permitindo ao povo dar continuidade à sua narrativa de forma humanizadora. Isso porque vemos a literatura, assim como Antonio Candido, cônscios de que ela nos interessa como experiência humana, não somente,

como produção de obras consideradas projeções, ou melhor, transformações de modelos profundos, a literatura desperta inevitavelmente o interesse pelos elementos contextuais. Tanto quanto a estrutura, eles nos dizem de perto, porque somos levados a eles pela preocupação com a nossa identidade e o nosso destino... ${ }^{8}$

A preocupação com nossa identidade e com nosso destino foi o facho que Chico Buarque tomou de José Martiniano de Alencar. Aquele, preocupado com nossa identidade, assim como o romancista do século XIX, lança-se para o passado recuperando a tradição e avaliando as contradições históricas, bem como mergulha no presente analisando os reveses de nossa sociedade contemporânea, dialogando com o Cânone do construto literário nacional, para nele, como intérprete da nação brasileira, posteriormente se inserir. Vai ao século XVII, com a peça Calabar $^{9}$ : o elogio da traição, acompanhado de Ruy Guerra. Em sua dramaturgia avalia a colonização brasileira, relativizando a posição do personagem Domingos Fernandes Calabar, no episódio em que este preferiu tomar partido ao lado dos holandeses contra a coroa portuguesa. Sem obedecermos a uma linha cronológica de produção de suas obras, Chico envereda pelo período da ditadura getulista, com a obra Ópera do Malandro, configurando meados do século XX. Com Paulo Pontes escreve Gota d'Água, a tragédia

\footnotetext{
${ }^{7}$ Idem, CANDIDO, Antonio, v.1, p. 282.

${ }^{8}$ CANDIDO, Antonio. A literatura e a formação do homem. IN: Textos de Intervenção. São Paulo: Duas Cidades, 2002, p. 79.

${ }^{9}$ Não nos esquecemos aqui a questão de que o Brasil vivia sob a opressão do regime ditatorial, sendo comum as metáforas nas produções artísticas com o intuito de burlar a censura do sistema. Mas não podemos engessar a obra literária dando a ela um referente, ou um alvo único, no caso o regime militar instituído no ano de 1964.
} 
da vida brasileira, na década de setenta. Nos anos 60, escreve Roda Viva, trabalhando o contexto da indústria cultural e televisiva que surge no Brasil dessa década; imergindo na crítica à ditadura com sua obra Fazenda Modelo, sem nos atermos a O Grande Circo Místico e sua filmografia, dirigindo-nos ao que nos interessa nesse ensaio: aos romances contemporâneos que vieram a público com Estorvo, em 1991; seguido de Benjamim, em 1995; Budapeste, em 2003, e, por fim, Leite Derramado, publicado em 2009. Este último, objeto de estudo neste ensaio.

O romance Leite Derramado constitui-se parte do novo romance histórico que desponta a partir da década de 80, com Viva o Povo Brasileiro, de João Ubaldo Ribeiro. Na mesma linha de Leite Derramado, surgem Heranças de Silviano Santiago; República dos Bugres, de Ruy Reis Tapioca; Os Rios Inumeráveis de Álvaro Cardoso Gomes. São obras que têm cunho epopeico. Narram a história da formação brasileira, a partir de um personagem. Dentre esses romances, o que mais se aproxima de Leite Derramado é o de Tapioca. Quincas, personagem cerne de A República dos Bugres, encontra-se na mesma situação de Eulálio, personagem do romance de Chico Buarque. Ambos estão num leito, rememorando as suas histórias particulares, as quais, ao mesmo tempo, são a metáfora de um Brasil que agoniza, em virtude de um construto histórico, cuja elite e povo viveram sempre dicotomicamente. O que há de comum na temática desses romances é o retrato de um Brasil, pintado a partir da “decadência” de famílias supostamente tradicionais. Os autores, ao criarem personagens que evocam as suas lembranças familiares, pretendem levar os leitores a revisitarem a história nacional, induzindo-os a refletirem tanto sobre o passado, quanto os valores contemporâneos. Nesses romances buscam-se polemizar questões que envolvem a identidade nacional brasileira, transformando-se em ficção histórica ${ }^{10}$, ao mesmo tempo em que procuram dar aos leitores subsídios para repensarem a nossa época e nossas raízes. Esse gênero de romance, parafraseando o texto do crítico Antonio R. Esteves, em O romance histórico brasileiro contemporâneo $^{11}$, pretende fazer uma revisão da história oficial do Brasil, escrita por vencedores e dominadores. A literatura passa a ter a pretensão de exercer a

\footnotetext{
10 Para melhor compreensão dessa terminologia consulte: HUTCHEON, Linda. Poética do pósmodernismo: história, teoria e ficção. Trad. Ricardo Cruz. Rio de Janeiro : Imago, 1991.

${ }^{11}$ ESTEVES, Antônio R. O romance histórico brasileiro contemporâneo. (1975-2000). São Paulo: Unesp, 2010. Nessa obra o critico literário aborda a visão do argentino Abel Posse, o qual possui uma série de romances publicados, dentre os quais destaca-se a trilogia de romances históricos que trata do período da colonização da América. Esteves, no capítulo 1: Narrativas de extração histórica: sob o signo do hibridismo, discorre sobre a pretensão histórico-crítica de Abel Posse em suas narrativas. Dessa sua análise é que nos apropriamos, haja vista que o romance histórico brasileiro parece-nos encerrar as mesmas pretensões ao revisitar a história nacional brasileira. Vide p. 17-30.
} 
função de desmitificar a história para tentar descobrir uma versão ou mais justa, ou mais condizente com os atores sociais.

Esse crítico da literatura contemporânea aborda que, segundo Abel Parentini Posse $^{12}$,

\begin{abstract}
houve um encobrimento consciente e inconsciente da realidade histórica americana. Compete aos escritores des-cobrirem a versão mais exata da história americana, para dar voz aos esquecidos, excluídos, oprimidos, vencidos. Nesse sentido, a literatura latinoamericana, e é esse o termo usado por Posse, além do estritamente estética, cumpre uma função desmitificadora. ${ }^{13}$
\end{abstract}

Esteves apropria-se do pensamento de Abel Posse, em virtude de se tratar de um escritor que se insere no mesmo período de produção dos romances históricos contemporâneos. O romancista elabora sua obra de 1970 com Los Bogavantes a Cuando muere el hijo, $2009^{14}$, período esse em que a narrativa brasileira também assimila esse gênero literário ${ }^{15}$. Porém, não é de nossa intenção, neste ensaio, abordar se o romance histórico possui realmente essa força e característica desmitificadora, ou a competência discursiva de des-cobrir uma versão mais exata das histórias nacionais. Nosso objetivo maior é apresentar o romance de Chico Buarque dentro de uma perspectiva literária histórica, assim como verificar que releitura é efetuada pelo autor de Leite Derramado sobre a história de nossa tradição, e qual seu olhar sobre o presente. Isso porque, o autor é homem de um tempo e a arte é um fator social, segundo nos afirma Antonio Candido. Para esse crítico, a literatura

depende da ação de fatores do meio, que se exprimem na obra em graus diversos de sublimação; e produz sobre os indivíduos um efeito prático, modificando a sua conduta

\footnotetext{
${ }^{12}$ Abel Parentini Posse, conhecido como Abel Posse (Córdoba, 7 de janeiro de 1934) é um ensaísta e escritor argentino, autor de diversas novelas. Seu último romance publicado foi Cuando muere el hijo. Una crónica real, 2009.

${ }^{13}$ ESTEVES, idem, p. 21.

${ }^{14}$ ESTEVES, idem, p. 21.

${ }^{15} \mathrm{Em}$ se tratando da literatura que surge na década de 80 em diante, Flora Sussekind aborda em seu ensaio Ficcão 80: dobradiças \& vitrines: "Mas não é só via romance policial que se retoma a ligação com a tradição literária brasileira recente. João Ubaldo e Jorge Amado, com o modelo do romanção, reforçando os laços entre a prosa literária e a mímesis da História (mesmo que a não oficial, a "popular"), agradam a livreiros ("livros grossos"/alto preço de capa), à crítica jornalística (Sempre apaixonada pelo romance - "expressão de um povo") e ao público, que recupera assim identidades étnico-nacionais, sob ameaça de dissolução na prosa ensaístico-ficcional, na metamídia recente." SUSSEKIND, Flora. Ficç̧ão 80: dobradiças \& Vitrines. IN: Literatura e Vida Literária, Rio de Janeiro, Zahar, p. 89.
} 
e concepção do mundo, ou reforçando neles o sentimento dos valores sociais. Isto decorre da própria natureza da obra e independe do grau de consciência que possam ter a respeito os artistas e os receptores de arte. ${ }^{16}$

Respaldados em Candido, buscamos investigar em Leite Derramado as influências exercidas pelos fatores socioculturais, porque elas repercutem e atuam socialmente. Trata-se de um sistema simbólico de comunicação inter-humana e como tal nos interessa. Nesse sentido, é possível darmos continuidade à análise do romance de Chico Buarque, afirmando que a narrativa desse autor extrapola a sua fábula para inserir em seu corpus todo um externo histórico-social, com o qual o leitor se identifica. Portanto, não podemos nos limitar a uma leitura fabular da história da família do personagem de Eulálio Montenegro de Assumpção. A textualidade de Leite Derramado dialoga com a tradição lítero-sociológica o que inviabiliza uma leitura fabular, posto que redutora. Leite Derramado encerra em sua textualidade a concepção de um Brasil mapeado por Sérgio Buarque de Holanda, em Raízes do Brasil, em se tratando da ausência de objetividade no espaço público brasileiro, a aversão à construção de nossos costumes de forma exógena e as consequências do homem cordial para a nossa sociedade. Um Brasil interpretado em Casa Grande e Senzala, por Gilberto Freyre, na abordagem em que este faz das relações entre o senhor e o escravo; à retomada do comportamento dissimulado da personagem Capitu, em Machado de Assis; chegando contemporaneamente às discussões encetadas por Roberto Schwarz em seu texto Nacional por Subtração; sem nos alongarmos a mencionar toda intertextualidade com aqueles que, nas palavras de Silviano Santiago ao referir-se aos intérpretes do Brasil, iluminaram "não só a vasta extensão e multifacetada região em que vivemos, como também a nós, habitantes que dela somos, alertando-nos para os acertos quantos os desacertos 17 históricos. Assim como esses intérpretes, mergulhando ora num, ora noutro, Chico Buarque, a partir de sua textualidade, vai também iluminando o leitor ao mostrar o painel de um Brasil sempre para fora, construído de forma exógena. Soma-se a toda essa intertextualidade, consciente ou inconscientemente, o texto de Antonio Candido, Dialética da Malandragem, ao retomar a questão do malandro em seu romance. Todo esse entranhamento textual e diálogo com a tradição conferem ao

\footnotetext{
${ }^{16}$ CANDIDO, Antonio. A literatura e a vida social. IN: Literatura e Sociedade. Estudos de teoria e história literária. 8. Ed. São Paulo: T. A. Queiroz, 2000, p. .20-21

17 Utilizamo-nos das palavras de Silviano Santiago, ao abordar sobre o papel dos intérpretes do Brasil para a nossa nação. Vide SANTIAGO, Silviano [org] Intérpretes do Brasil. V.1. Rio de Janeiro: Aguilar, 2002, p. XV
} 
romance de Chico plurivalência e elasticidade, viabilizando à narrativa extrapolar a si mesma, dialogando com o externo do qual emerge.

A elasticidade e plurivalência no romance Leite Derramado tornam-se visíveis, na medida em que os rastros históricos presentes na narrativa impedem o leitor de prescindir dos dados externos, visto que esses se transformam em condições sine qua non para a compreensão do interno da obra. A fábula do romance deixa seu próprio pertencimento, para voltar-se contra o leitor, fazendo-o perceber as atrocidades na construção de sua nação, assim como os reflexos da ausência de valores na sociedade contemporânea. Nesse jogo de interno e externo, a história de Eulálio Montenegro de Assumpção adquire uma dimensão maior. O romance, numa leitura menos interessada, apresenta-se tão-somente como a história da família Assumpção que se torna conhecida através da fala de um velho, imersa em outras falas midiáticas, a exemplo de uma televisão a qual o perturba o dia inteiro: "Fica essa televisão ligada o dia inteiro, as pessoas aqui não são sociáveis. "18. Os novos meios de comunicação impedem a fluidez de suas memórias, haja vista que o exterioriza, inviabilizando a sua interiorização e, consequentemente, a retomada de sua cultura, interditando a interlocução com o outro, posto que ele não consegue ser ouvido. Tal enfoque da força da mídia internalizada no romance, parece-nos trazer à tona, de certa forma, a denúncia da morte da literatura, visto que o espaço privilegiado de discurso produtor de sentido foi preenchido pelos novos meios de comunicação que surgem, não como instrumentos formadores da consciência, mas de ruído. As memórias desse velho centenário, dialogando com o externo, transformam-se, no romance de Chico Buarque, num afresco da história da República Brasileira. Ao leitor cabe aqui e acolá no texto, ligar as pontas de uma narrativa que lhe chega de forma esquizofrênica ${ }^{19}$. O monólogo de Eulálio se dirige à filha Eulália e a uma suposta enfermeira do hospital em que ele se encontra internado. Suas memórias não são dadas de forma linear, o adágio "pai rico, filho nobre, neto pobre ${ }^{20}$ é que se apresenta como o fio condutor maior da narrativa. Em constantes flashback's, o narrador senil mergulha em suas memórias à procura de um tempo perdido, numa repetição incansável dos fatos, fazendo com que o texto perca a sua fluidez, revelando não só a memória dos velhos, mas uma história nacional que se encontra abandonada e fragmentada na sociedade brasileira. Como dissemos

\footnotetext{
${ }^{18}$ BUARQUE. Leite Derramado, p. 11

${ }^{19}$ Quanto à esquizofrenia contemporânea leia-se em JAMESON, Fredric. Pós-Modernismo e a Lógica cultural do capitalismo tardio. São Paulo: Ática, 1996.

${ }^{20}$ BUARQUE, idem, p. 38.
} 
anteriormente, não há interlocutores. O único personagem visível para o leitor é o narrador, os outros em nenhum momento se manifestam, ou se configuram. E se tomam forma, é única e exclusivamente pela narrativa de Eulálio. Não há falas, e todas as ações das personagens são conhecidas a partir das memórias de Eulálio; filho de uma linhagem de Eulálios. Assim se chamou seu tataravô, bisavô, avô e pai, revelando uma tradição advinda desde o Império, ou em memórias vagas, indo mais além no passado, remontando à história de Portugal. Suas memórias vão se conectando a uma e a outra passagem da história do Brasil, mas são como o próprio narrador afirma “(...) um pandemônio, mas está tudo lá dentro, depois de fuçar um pouco o dono é capaz de encontrar todas as coisas". ${ }^{21}$

Em busca dessa tecedura, procurando unir os fios que se encontram lá dentro, dispersos, o narrador vai, em suas sucessivas etapas da vida da fazenda, onde morava o avô, depois para o sobrado, período ainda em que ele se encontrava sobre a égide do pai forte e de uma mãe austera, depois para o chalé, momento de sua vida em que estava casado com Matilde e, posteriormente, sua derrocada final para um apartamento, outro menor, até chegar à hospedagem, e por fim ao leito do hospital, sem saber mais para onde se destinaria. Sua história se estende desde as lembranças dos antepassados advindos de uma linhagem, quiçá inventada, de homens fortes, prósperos a exemplo de seu tetravô general, "filho de dom Eulálio, próspero comerciante da cidade do Porto, que comprou o chicote em Florença com o intuito de fustigar jesuítas. „22. Esse chicote fora passado de pai para filhos. Era símbolo de homens destemidos, fortes, seja em influência social, política, ou sexual. Em oposição a esses homens dominadores, encontra-se o último Eulálio. Este vivia da renda que o pai deixara. O Eulálio narrador, ao contrário do pai, era homem de uma só mulher, sobre a qual paira, em todo decorrer da narrativa, o espectro da traição à la Capitu, de Machado de Assis. Assim como não há provas cabais de que a personagem machadiana traiu Bentinho, também não as há de que Matilde traiu Eulálio. E essa dúvida faz com que Matilde se transforme na linha condutora da narrativa, passando a significar na vida de Eulálio uma eterna sombra, assim como Capitu, para Bentinho. A imagem que Eulálio faz de Matilde é sempre de uma mulher dissimulada, desde o momento em que a conheceu em sua juventude na igreja, e, posteriormente, no velório do seu Pai: "Vi como ela se aproximava não em linha reta, mas em parafuso, a se entreter com meio mundo à sua volta, como se

\footnotetext{
${ }^{21}$ BUARQUE, Chico. Leite Derramado. São Paulo: Cia das Letras, 2009, p. 41

${ }^{22}$ BUARQUE, idem, p. 103.
} 
estivesse numa fila de sorveteria."23 A semelhança com a personagem machadiana é tácita. Ao estabelecer esse diálogo, Chico Buarque resgata a percepção de Machado de Assis, quanto ao caráter nacional, tão presente em seus romances. Este espírito se encontra entranhado em toda a narrativa de Leite Derramado. E se em Machado, Bentinho é arrastado pelos olhos de ressaca de Capitu ${ }^{24}$, Eulálio é seduzido pelos olhos meio árabes de Matilde:

Porque com seus olhos apenas, aqueles olhos meio árabes, Matilde dava a entender seus menores movimentos de corpo, o sutil balanceio dos seus quadris, e tive de correr para casa, eu precisava de um banho fresco. ${ }^{25}$

Mas o diálogo com a tradição se adensa, não se limitando à obra machadiana. $\mathrm{O}$ leitor pode intuir semelhanças entre essa personagem e à muiraquitã, que fora roubada de Macunaíma pelo gigante Pietro Pietra Piaimã ${ }^{26}$. Matilde passa a constituir-se como uma identidade roubada, também por um europeu, neste caso, Dubosc, um francês, sobre quem pairava a dúvida da traição. Este, segundo o narrador, "era um engenheiro nervoso. Mal tinha chegado ao país e queria encontrar todas as portas abertas, ou senão explodi-las a dinamite.”27 Dubosc fora se aproximando do chalé de Eulálio, e tendo intimidades com sua esposa, a ponto de dançar com Matilde o maxixe ${ }^{28}$, ritmo considerado imoral nesse período pela elite brasileira:

Le maxixe!, exclamou o francês, é magnífico o ritmo dos negros!, e nos pediu que dançássemos para ele ver. Mas eu só sabia dançar a valsa, e respondi que ele me honraria tirando minha mulher. No meio do salão os dois se abraçaram e assim permaneceram, a se encarar. $^{29}$

\footnotetext{
${ }^{23}$ BUARQUE, idem, p. 31.

${ }^{24}$ ASSIS, Machado de. Dom Casmurro. Rio de Janeiro: Aguilar, 1979, p. 842-843. Tal semelhança pode ser lida no capítulo XXXII/Olhos de Ressaca, de Dom Casmurro. Eulálio, personagem de Leite Derramado, vê-se envolvido por Matilde da mesma forma que a personagem machadiana se vê arrastada pelo olhar de Capitu. A dissimulação é uma constante nas obras desse romancista do século XIX e início do XX. Está presente nas personagens Marcela e Virgília, na Obra Memórias Póstumas de Brás Cubas, e mesmo em Cubas. Salta para a personagem Sofia, em Quincas Borba, para ser trabalhada com maior densidade em Dom Casmurro, na personagem Capitu, sem fazer registro de outros tantos vários contos, a exemplo de A Cartomante.

${ }^{25}$ BUARQUE, idem, p. 138.

${ }^{26}$ Vide. ANDRADE, Mário. Macunaíma. São Paulo: Círculo do Livro, 1989.

${ }^{27}$ BUARQUE, idem, p. 43.

${ }^{28} \mathrm{O}$ movimento dos corpos e o apelo aos sentidos constituíam também uma resposta individual às distâncias em relação ao público e ao impessoal. Como nos movimentos do maxixe, uma dança banida dos lares, por indecorosa. Vide. SALIBA, Elias Thomé. A Dimensão Cômica da Vida Privada na República. IN: NOVAIS, Fernando A. História da Vida Privada no Brasil República: da Belle Epoque à Era do Rádio. São Paulo: Companhia das Letras, 1998, p. 322.

${ }^{29}$ BUARQUE, idem, p. 65.
} 
A narrativa de Chico Buarque não se limita a dialogar somente com essas obras, estabelece intertextualidade com Amar, verbo intransitivo, de Mário de Andrade, ao resgatar a figura da governanta alemã: "De nada adiantou mamãe contratar a governanta alemã, quando achou que eu estava muito crescido para ter babá.”30. Retoma, outrossim, os discursos do caráter nacional brasileiro, a exemplo do malandro nacional, fornecendo ao leitor, uma reflexão sobre as consequências da apropriação das ideias importadas e do abandono da tradição (mesmo que carregada de contradições), para transformar-se num país novidadeiro, povoado por um povo voltado para fora, reafirmando o dizer do Padre Manuel da Nóbrega, em carta de 1552:

[...] de quantos lá vieram, nenhum tem amor a esta terra. [...] todos querem fazer em seu proveito, ainda que seja a custa da terra, porque esperam de se ir [...] Não querem bem à terra, pois têm sua afeição em Portugal; nem trabalham tanto para a favorecer, como por se aproveitarem de qualquer maneira que puderem; isto é geral, posto que entre eles haverá algum fora desta regra ${ }^{31}$.

Ou, mais hodiernamente, reforçando o pensamento de Roberto Schwarz. Em Leite Derramado, retrabalha o mal-estar em nossa civilização, ou seja, retoma a questão do complexo de ser brasileiro, de um povo que só é capaz de se ver por subtração com relação à sociedade da qual é cópia, carregando consigo o sentimento de inferioridade, nas palavras de Schwarz, comportando "o sentimento da contradição entre a realidade nacional e o prestígio ideológico dos países que nos servem como modelo" 32 . As etapas de moradias de Eulálio vão, ao resgatar essas questões, dando ao leitor uma imagem do brasileiro e das relações entre estamentos sociais, bem como da ideia de um povo cujo apetite

pela produção recente dos países avançados muitas vezes tem como avesso o desinteresse pelo trabalho da geração anterior, e a consequente descontinuidade da reflexão. Conforme notava Machado de Assis em 1879 'o influxo externo é que determina a direção do movimento’ Que significa a preterição do influxo interno, aliás menos inevitável hoje do que naquele tempo? Não é preciso ser adepto da tradição ou de uma impossível autarquia intelectual para reconhecer os inconvenientes desta praxe, a que falta a convicção não só das teorias, logo trocadas, mas também de suas implicações menos próximas, de sua relação com o movimento social conjunto, e, ao fim e ao cabo, da relevância do próprio trabalho e dos assuntos estudados. ${ }^{33}$

\footnotetext{
${ }^{30}$ BUARQUE, idem, p. 104.

31 IN: TAPIOCA, Ruy Reis. A República dos Bugres. Rio de Janeiro: Rocco, 1999, p. 99.

${ }^{32}$ SCHWARZ, Roberto. Que horas são? São Paulo: Companhia das Letras, 1987, p. 30.

${ }^{33}$ SCHWARZ, idem, p. 30-31.
} 
Os tempos do Casarão representam a época da geração do pai, tempos da nobreza, avessa ao povo. Essa impossibilidade de empatia entre as classes era o que impedia Matilde de ser assimilada pela família de Eulálio, em virtude de ela ter a tez amorenada; além de que, por advir de uma família não pertencente à classe social dos Assumpção, era considerada alguém indigna de casar-se com Eulálio. Essa inaceitação, tanto familiar quanto social, estava internalizada no narrador, inviabilizando um processo dialético entre as classes representadas pelos personagens, a ponto de ele estar sempre vendo Matilde, a partir do olhar do francês Dubosc e do médico judeu Dr. Daniel Baumblaun. Não é por acaso que as notícias que chegam a Eulálio sobre sua esposa vêm sempre de fora. O porta-voz e o sabedor do paradeiro de Matilde é o doutor Daniel. A partir dessa impossibilidade de saber onde se encontrava Matilde, são criadas versões sobre seu possível paradeiro. Como se o autor quisesse induzir o leitor à percepção de que sua identidade foi produzida a partir do fora, de forma exógena, nunca endogenamente.

Contudo, não para aí a percepção do autor. Numa leitura sagaz da realidade, leva à exaustão em sua narrativa a pretensão de registrar aspectos da sociedade, inserindo fatos e acontecimentos históricos passados, com o intuito de confrontá-los com o presente, revelando assim o esmaecimento ${ }^{34}$ de todos os valores contemporaneamente. Nessa pretensão, confronta pai e filho, a mãe, esposa e filha, para dar conta da contradição em que Eulálio vive das duas temporalidades. Tempos em que o narrador vê como áureos, tempos em que não dando conta da nova história, das novas relações sociais, as considera, inevitavelmente, decadentes. Ao traçar um paralelo entre o passado e presente, o narrador apresenta seu pai como um representante desse tempo áureo de outrora. Rigoroso, mesmo nas vestes e no trato, de aparência nobre, falava bom francês. Considerado um homem de múltiplos interesses, mulherengo, mas que nunca saía do sério, era o Senador Eulálio de Assumpção. Resolvia com um telegrama qualquer pendenga, ao contrário do filho que tinha que comparecer pessoalmente às repartições. O pai era um viajor, alguém que vinha de longe e trazia em suas entranhas as experiências da vida; enquanto o filho era sedentário, deambulava sem nenhum projeto de vida. O Pai vivia constantemente nos transatlânticos a caminho da Europa; o

\footnotetext{
${ }^{34}$ Para Fredric Jameson, ocorre na sociedade contemporânea o esmaecimento da cultura, do afeto, do amor, bem como a ausência de profundidade nas relações. JAMESON, Fredric. Pós-Modernismo: a lógica cultural do capitalismo tardio. São Paulo: Ática:, 1996.
} 
filho findara sua última aparição pelo velho continente, ou à “civilização”35, quando do Crack da bolsa de Nova York. Nessa última viagem, fora acomodado com os argentinos, vendo pouco a pouco esvaziar o seu prestígio no Lutétia, "talvez porque já me falhasse o francês fluente do meu pai”, ${ }^{36}$ O pai era um nome; o filho, um eco ${ }^{37}$. Este viveu tal qual Brás Cubas $^{38}$, personagem machadiano. Não alcançou nenhuma celebridade, não chegou a ser senador. A ele não se pode atribuir o ditado: "tal pai, tal filho”. Se conheceu o casamento, foi abandonado e supostamente traído. Teve seu saldo positivo: não comeu o pão com o suor do rosto, não teve filho homem; antes uma filha, Maria Eulália. Entretanto, esta, segundo o narrador, diante de uma tradição de filhos homens dos Assumpção, “quem sabe não se culpava até mesmo por ter nascido menina, julgando que eu contava com um herdeiro" ${ }^{39}$. Este representa na narrativa o primeiro sinal de decadência da família Eulálio de Assumpção. Seu nome seria substituído por Palumba, filho de Américo Palumba. Os Eulálios das gerações seguintes iriam sofrendo a miscigenação, tanto do nome, quanto da cor. Seu bisneto nasceria negro, num presídio, de ascendência duvidosa. Dúvida esta externada na fala do narrador:

Cá entre nós, tenho dúvidas quanto à ascendência do rapaz, dado como filho póstumo do meu bisneto Eulálio. Os senhores vão cair para trás, mas meu bisneto era tão preto quanto o chefão aí da quadrilha. ${ }^{40}$

Somando-se à miscigenação, o nome Assumpção perderia a sua relevância, passando a ser um nome intermediário, para dar lugar ao sobrenome Palumba. Mesmo tendo a tradição do nome de sua família nomeado ruas; perpetuando a memória dos Palumba, ninguém mais queria saber de seu nome, ou dessa tradição. Quando o narrador a evoca, com o intuito de favorecer-se dela, ao dizer a um chofer de táxi: “(...) escute aqui, senhor, eu sou bisneto do barão de Arcos.",41, resgatando o célebre "você sabe com quem está falando?" 42 , ouve como resposta do chofer:

\footnotetext{
${ }^{35}$ BUARQUE, idem, p. 59.

${ }^{36}$ BUARQUE, idem, p. 58

${ }^{37}$ Leia-se como o personagem narrador se coloca diante da tradição à qual representa. BUARQUE, idem, p. 31

${ }^{38}$ ASSIS, Machado de. Memórias Póstumas de Brás Cubas. Cap. CLX /Das Negativas. Rio de Janeiro: Aguilar, 1979, p. 639.

${ }^{39}$ BUARQUE, idem, p. 125.

${ }^{40}$ BUARQUE, idem, p. 168

${ }^{41}$ BUARQUE, idem, p. 50.

42 Sobre o poder dessa expressão, leia-se "Teoria e prática do "Sabe com quem está falando?" de Roberto DaMatta. Para esse pensador a expressão "Sabe com quem está falando?" é utilizada nas seguintes condições: (a) sentir sua autoridade ameaçada (ou diminuída); (b) desejar impor de forma
} 
Aí ele me mandou tomar no c... mais o barão, desaforo que nem lhe posso censurar. Fazia muito calor no carro, ele era um mulato suarento, e eu a me dar ares de fidalgo. Agi como um esnobe, que como vocês devem saber, significa indivíduo sem nobreza ${ }^{43}$.

O velho Eulálio permaneceu carregando a maldição da família, mas na condição de ter um único filho, como lhe dissera sua mãe:

[...] porque os Assumpção só fazem filho homem. E disse que os Assumpção têm sempre um filho só, é maldição da família, antes de mim ela própria perdera cinco, e cinco vezes por pouco não morria de eclampsia. ${ }^{44}$

Não obstante, com ele findou a tradição de gerar machos que dessem aos Assumpção uma descendência. A partir de sua filha Eulália, inicia o processo de decadência social e moral na visão do narrador. Doravante, a narrativa passa a apresentar uma tradição de netos pobres, tanto econômica quanto culturalmente.

Nas falas em que há a marca de estranhamento. em relação ao que era considerado normal no mundo de Eulálio, representa para ele um processo de decadência social. Junto à sua derrocada econômica, a narrativa vai assimilando uma nova classe social que ascende, representada pelos Palumba. Mas essas vozes continuam a ser filtradas com estranheza pela visão de mundo do velho Eulálio. Já não há mais a grande história dos machos. Sua filha, Maria Eulália, acrescentara ao Assumpção um Palumba, dando novo rumo à história da família do narrador. O marido de Eulália, Amerigo Palumba, trapaceia a família e a abandona. Nesse momento, Eulálio reconhece que,

como se dizia antigamente, pai rico, filho nobre, neto pobre. O neto pobre calhou de estar na sua barriga, Eulálio D’Assumpção Palumba, o garotão por nós criado, que cresceu rebelde com toda a razão. ${ }^{45}$

Rompeu-se a tradição, os tempos áureos terminaram. Se a história da qual ele participava ainda como sujeito lhe era um pandemônio, agora, suas lembranças são mais vagas com relação aos netos. Não consegue mais atribuir os acontecimentos aos sujeitos

cabal e definitiva seu poder; (c) inconsciente ou conscientemente perceber no seu interlocutor uma possibilidade de inferiorizá-lo em relação ao seu status social; (d) for pessoa interiormente fraca ou que sofre de complexo de inferioridade; (e) o interlocutor, de uma forma ou de outra, é percebido como ameaça ao cargo que ocupa. IN: DaMatta, Roberto. Carnavais, Malandros e Heróis: para uma sociologia do dilema brasileiro. 6a. Ed. São Paulo: Rocco, 1997, p. 187.

${ }^{43}$ BUARQUE, idem, p. 50.

${ }^{44}$ BUARQUE, idem, p. 64.

${ }^{45}$ BUARQUE, idem, p. 38. 
de forma precisa, visto que signo e significante se perdem para ele. Em seu olhar desgarrado, próprio dos velhos, busca o passado, para dele evocar imagens da memória, procurando amparo em coisas distantes, porque é nela que repousam as crônicas de sua vida particular e do meio em que viveu. Único porto seguro que encontra, haja vista que o presente se fragmenta e o confunde, tornando-se impossível dar conta da realidade presente:

[...] sinceramente não dou mais conta desta filharada que deu para nascer de uns anos para cá. Em compensação, sou capaz de me lembrar de cada fio de cabelo do coque de minha mãe, que havia tempos eu não via." ${ }^{46}$

A memória de Eulálio busca resistir a uma nova geração que não estava mais preocupada com sua história. Maria Eulália, assim como Matilde, não carregavam mais o coque de sua mãe. Os meios de comunicação passaram a determinar o comportamento da mulher, e Matilde, dominada pelos elementos da modernidade, passa a ter um novo comportamento: “(...) corta os cabelos à La garçonne.”47, além de apresentar-se “(...) muito corada e com ruge demais”48 . Já sua filha "perdeu muito de sua finesse depois que se misturou com uma gente de maus bofes" ${ }^{49}$. E a nova mulher perde totalmente o nexo com os laços morais da tradição. O retrato moral da nova mulher nada mais condiz com a história enovelada no coque da mãe do velho Eulálio:

Eu estava justamente pondo ordem nos papéis, no dia em que Eulálio [tataraneto] entrou em casa com uma namoradinha chamada Kim. De saia curta e barriga de fora, uma argola espetada no umbigo, era uma brunette extrovertida, foi logo me dando beijinhos e me tratando por você. Sentou-se no braço da minha cadeira e se divertiu com as minhas fotografias, na altura do seu cóccix estava tatuado Jesus Cristo em letras góticas. ${ }^{50}$

A vida de Maria Eulália, mulher abandonada pelo marido, transforma-se numa construção de violência aos valores de seu pai. Do texto, pode-se inferir duas relações homossexuais de Eulália. No primeiro relacionamento, fora induzida por uma pintora e, posteriormente, por uma atriz; ambas trazendo sérios prejuízos econômicos para a família. A violência à mulher é trazida ao texto não somente pela quebra de valores morais, mas também pela agressão física que Maria Eulália sofre. Solitária, amiga-se

\footnotetext{
${ }^{46}$ BUARQUE, idem, p. 195.

${ }^{47}$ BUARQUE, idem, p. 11.

${ }^{48}$ BUARQUE, idem p. 12.

${ }^{49}$ BUARQUE, idem, p. 146.

${ }^{50}$ BUARQUE, idem, p. 171.
} 
com Xerxes, "um grandalhão com cara de nortista, nariz chato, pele grossa” ${ }^{\text {. }}$. Desaparece do texto o conceito de matrimônio, para dar lugar às relações periféricas, e, com ela, o desrespeito à mulher: "Porque o Xerxes, quando bebia, costumava bater na minha filha, mas em bairros mais populares cenas do gênero são corriqueiras, não escandalizam ninguém." 52 Diante das agressões sofridas e da falência, nada mais resta à sua filha do que correr em busca de soluções milagrosas: ingressa na igreja evangélica, esquecendo-se de sua história, entregando, por fim, a sua consciência ao pastor da Igreja Evangélica do Terceiro Templo.

Corre, paralelamente a todas essas mudanças de valores, a queda do Casarão. O chalé que se molda à arquitetura contemporânea, a fazenda que desaparece sob a nova realidade e a memória constante de Matilde presente como uma sombra. Por detrás das transformações, a televisão continua ligada no futebol em meio a tantos estertores, impossibilitando o velho Eulálio concentrar-se nos seus assuntos. Mas, se o leitor esperava que a degradação encerrasse; finda a narrativa, o velho, na enfermaria, exposto ao acaso, ainda tem a dizer:

O ambiente ainda se degradava à medida que recebíamos os excedentes do pronto-socorro, pacientes com o rosto desfeito, queimaduras, perna amputada, bala na cabeça. Eram jovens, em geral, e malcriados, nem bem eu abria a boca e já manifestavam: não fode, vovô, conta outra! ${ }^{53}$

As transformações sociais apontadas pelo narrador, no decorrer de sua narrativa, apontam para um mundo caduco, no qual houve o esmaecimento do amor, da amizade, da autoridade e do nome. Mas o mundo de que parte Eulálio para avaliar o presente, é um mundo também conflituoso; no entanto, sem vozes que pudessem exprimir as contradições existentes. Quando a elite tem uma determinada prática-social, esta não fica ensimesmada na própria classe. As práticas, consideradas “limpas” enquanto exercício da classe dominante, engendram-se por todos os estamentos sociais, em virtude de serem divulgadas pelas novas forças que surgem, a exemplo da mídia, e passam a ser reproduzidas por todas as instâncias sociais. Lembremos que não causa nenhum estranhamento a Eulálio os relacionamentos que seu pai tinha fora do casamento, tampouco, a cocaína que fumava. Essas transgressões eram vistas como um ato de firmeza do caráter paterno. Todavia, as mesmas transgressões, quando praticadas

\footnotetext{
${ }^{51}$ BUARQUE, idem, p. 142.

52 BUARQUE, idem, p. 143

${ }^{53}$ BUARQUE, idem, p. 184
} 
por representantes de outras classes sociais (no caso netos, ou bisnetos), foram encaradas pelo narrador como frutos da decadência moral dessa nova geração. Diante dessa perspectiva do narrador, cabe ao leitor estar atento e perguntar-se, se antes de haver uma decadência dos valores sociais, não haveria, tão-somente, uma extensão das práticas da elite às outras classes, transformando-se em natural, aquilo que era somente natural para uma determinada casta, visto que praticava no suposto “decoro” de seu lar, num código seleto, no caso o francês, conferindo ao ato imoral, um certo tom de moralidade e de prestígio.

Por se tratar de um texto monológico, o leitor tem que colocar em suspensão as afirmativas do velho Eulálio, saudoso da condição que seu estamento lhe conferia, e avaliar se a mudança do poder dos Assumpção para os Palumba significa uma decadência dos valores, ou se se trata de novas formas de convívio. Não se pode perder de vista que nesse jogo de passado e presente, o velho Eulálio representa uma elite saudosa de uma época em que as contradições não vinham à visibilidade. Essa elite vivia num período cujo chicote imperava; a mulher, o negro e outras minorias não tinham voz; sendo possível visualizar um momento em que tudo era idílico. Talvez seja mais pertinente afirmar que, no Brasil, ocorreu a decadência de uma elite, que se considerava dona do poder, a despeito de toda uma população que vivia sem "beber do leite que fora derramado”. É notório que a sociedade brasileira, assim como outras, passa por crises de autoridade, morais, culturais; mas se lermos a história a partir da perspectiva de uma classe que se outorga o direito de ser e representar a nação, estaremos sendo coniventes com ela, ao afirmar que tudo quanto lhe é desvio de norma será inatural e decadência. Partindo-se da ótica de que o autor de Leite Derramado pertence a um topos, no caso, advém de uma família tradicional brasileira, parece-nos estar internalizado no romancista o que Alain Finkielkraut aborda em A Humanidade Perdida, ${ }^{54}$ com relação ao século XIX. Segundo esse pensador, este século tinha uma confiança exagerada e um pouco pueril no poder que o homem exercia sobre si mesmo e no poder dos povos sobre seus próprios destinos. Agora vive-se no excesso oposto. Se outrora, acreditávamos em tudo poder, hoje cremos nada poder e gostamos de acreditar que a luta e o esforço doravante são inúteis. Não é por acaso que Eulálio tenta explicar ao seu neto, o qual entrara na resistência contra o regime militar imposto ao Brasil em

\footnotetext{
${ }^{54}$ FINKIELKRAUT, Alain. A humanidade perdida: Ensaio sobre o século XX. São Paulo: Ática, 1996, p. 54.
} 
64, “que o heroísmo é uma vulgaridade.”55. O nada poder transformou-se na grande enfermidade de nosso tempo, enfermidade totalmente oposta a de nossos pais.

Chico Buarque, ao olhar para o passado de homens afeitos à luta, através de seu personagem, quem sabe, não visualizou uma sociedade contemporânea enferma, composta por homens sem fibra, assemelhando-se o seu olhar aos olhares de outros autores hodiernos, a exemplo de Silviano Santiago, em Heranças, Ruy Reis Tapioca, em A República dos Bugres, ou Álvaro Cardoso Gomes, em seu Rios Inumeráveis. De certa forma, cada um desses autores está a abordar essa sociedade enfermiça e a dizer, a seu modo, o que nos disse Buarque em seu romance Leite Derramado. No entanto, mesmo diante dessa tragédia que nos é apresentada pelo autor, deparamo-nos com um texto angustiante, cético. Talvez, numa leitura atenta, nas entrelinhas da fala do velho Eulálio, ainda seja possível ver um pequeno broto e acreditar que, apesar de toda essa decadência e enfermidade apontadas pela voz de Eulálio, ainda existam possibilidades de transformação dessa condição social.

E nessa leitura atenta, assim como Eulálio Montenegro de Assumpção a caminho da hospedagem, possamos reconhecer algumas pegadas aqui e acolá, que nos façam reconhecer que se trata de marcas de um Brasil que vem de longe. Tal qual o narrador, sabemos que estamos a pisar no chão em que se encontram enterrados os nossos avós:

às vezes se reconhece num homem velho o trejeito infantil, mas lento apenas. Aquele era o ribeirão de minha fazenda na raiz da serra. E à beira-rio uma mangueira me pareceu tão familiar, que por pouco eu não ouvia o preto Balbino lá no alto..., ${ }^{56}$

O autor dialogou com diversos textos, nos fez parar em múltiplas casas para nelas dialogarmos com Freyre, Machado, Mário de Andrade, Candido, Schwarz e outros. E se uma das condições para que uma obra seja um clássico, segundo Ítalo Calvino, é que seja um livro que chegue

até nós trazendo consigo as marcas das leituras que precederam a nossa e atrás de si os traços que deixaram na cultura ou nas culturas que atravessaram (ou mais simplesmente na linguagem ou nos costumes ${ }^{57}$.

\footnotetext{
${ }^{55}$ BUARQUE, idem. P. 126.

${ }^{56}$ BUARQUE, idem, p. 178.

${ }^{57}$ CALVINO, Ítalo. Por que ler os Clássicos. São Paulo: Companhia das Letras, 1993, p. 11.
} 
Partindo-se desse pressuposto, é possível afirmar que Leite Derramado se trata de um clássico, por carregar consigo as marcas de nossa cultura, ao dialogar com a tradição e com seus contemporâneos. Reconhecido o resgate da tradição no texto, restanos voltarmos ao início de nosso trabalho, com o intuito de reforçar o que dissemos do autor de Leite Derramado. Chico Buarque toma o facho de José Martiniano de Alencar, ao revisitar a história nacional, sociologia e literatura, transformando-se em mais um intérprete do Brasil, ao dar ao leitor um afresco da formação da nação brasileira ao presente século, a partir do retrato ficcional da história da família Assumpção e Palumba.

\section{Referências}

ALENCAR, José Martianiano de. Como e por que sou romancista. São Paulo: Pontes, 2005.

ASSIS, Machado de. Dom Casmurro. Rio de Janeiro : Aguilar, 1979.

ASSIS, Machado de. Memórias póstumas de Brás Cubas. Rio de Janeiro: Aguilar, 1979.

ANDRADE, Mário. Macunaíma. São Paulo: Círculo do Livro, 1989.

BUARQUE, Chico. Leite derramado. São Paulo: Companhia das Letras, 2009.

. Estorvo. São Paulo: Companhia das Letras, 1991.

. Benjamim. São Paulo: Companhia das Letras, 1995.

. Budapeste. São Paulo: Companhia das Letras, 2003.

CALVINO, Ítalo. Por que ler os clássicos. São Paulo: Companhia das Letras, 1993.

CANDIDO, Antonio. Literatura e sociedade. Estudos de teoria e história literária. 8. ed. São Paulo: T. A. Queiroz, 2000.

CANDIDO, Antonio. Textos de intervenção. São Paulo: Duas Cidades, 2002.

CANDIDO, Antonio. Formação da literatura brasileira. 8. ed. - Belo Horizonte Rio de Janeiro: Itatiaia, 1997.

DAMATTA, Roberto. Carnavais, malandros e heróis: para uma sociologia do dilema brasileiro. 6. ed. São Paulo: Rocco, 1997.

ESTEVES, Antônio R. O romance histórico brasileiro contemporâneo (1975-2000). São Paulo: UNESP, 2010. 
FINKIELKRAUT, Alain. A humanidade perdida: ensaio sobre o século XX. Trad. Luciano Machado. São Paulo: Ática, 1998.

FREYRE, Gilberto. Casa grande e senzala. Rio de Janeiro: Aguilar, 1977.

GOMES, Álvaro Cardoso. Os rios inumeráveis. São Paulo: Topbooks, 1997.

HOLANDA, Sérgio Buarque de. Raízes do Brasil. 26. ed. São Paulo: Companhia das Letras, 1995.

HOBSBAWN, Eric. A invenção das tradições. 3. ed. Rio de Janeiro: Paz e Terra, 1997.

HUTCHEON, Linda. Poética do pós-modernismo: história, teoria e ficção. Trad. Ricardo Cruz. Rio de Janeiro : Imago, 1991.

JAMESON, Fredric. Pós-Modernismo: a lógica cultural do capitalismo tardio. São Paulo: Ática:, 1996.

LUKÁCS, Gyorgy. O Romance histórico. Trad. Rubens Enderle. São Paulo: Boitempo, 2011.

. Teoria do romance. Trad. José Marcos Mariani de Macedo. São Paulo: Duas Cidades, 2000.

SCHWARZ, Roberto. Que horas são? São Paulo: Companhia das Letras, 1987.

SANTIAGO, Silviano (Org.). Intérpretes do Brasil. V. 1. Rio de Janeiro: Aguilar, 2002.

. Heranças. Rio de Janeiro: Rocco, 2008.

SUSSEKIND, Flora. Ficcção 80: dobradiças \& Vitrines. In: Literatura e vida literária. Rio de Janeiro: Zahar, 2002.

TAPIOCA, Ruy Reis. A república dos bugres. Rio de Janeiro: Rocco, 1999.

WEINHARDT, Marilene (Org). Ficção histórica: teoria e crítica. Ponta Grossa: Editora UEPG, 2011. p. 12-55. 